\title{
OPTIMIZATION OF ETHANOL AUTOTHERMAL REFORMING PROCESS WITH CHEMICAL EQUILIBRIUM CALCULATIONS
}

\section{ETANOLA AUTOTERMISKĀ PĀRVEIDOŠANAS PROCESA OPTIMIZĀCIJA AR ĶĪMISKĀ LİDZSVARA APRĒḲINIEM}

\section{D.Markova, Ms.ing., researcher}

Institute of Energy Systems and Enviroment, Riga Technical University Address: Kronvalda boulv. 1, LV-1010, Riga, Latvia

Phone: 00371+2685682, Fax: 00371+67089908

e-mail: darja.markova@rtu.lv

K.Valters, Dr.chem., assistant professor

Institute of Energy Systems and Enviroment, Riga Technical University Address: Kronvalda boulv. 1, LV-1010, Riga, Latvia Phone: 00371+67089908, Fax: 00371+67089908 e-mail: karlis@norden.lv

G.Bažbauers, Dr.sc.ing., profesor Institute of Energy Systems and Enviroment, Riga Technical University Address: Kronvalda boulv. 1, LV-1010, Riga, Latvia Phone: 00371+67089911, Fax: 00371+67089908 e-mail: gatis.bazbauers@rtu.lv 
Keywords: autothermal reforming, chemical, ethanol, equilibrium, fuel cells, optimization

\section{Introduction}

The reduction of the dependence on imported fossil fuels and an increase in the share of renewable energy sources are very important tasks for Latvia. High efficiency fuel cell cogeneration plants operating on ethanol produced from local biomass and subsequently reformed to a hydrogen-rich gas can help to fulfil the above mentioned tasks. As the ethanol reforming process plays a critical role in the determination of the overall efficiency of a fuel cell cogeneration system, it is very important to choose the best operational conditions in order to produce the maximum hydrogen amount in the reformed gas and to achieve the maximum process efficiency.

Apart from achieving the maximum hydrogen yield and process efficiency, it is also very important to avoid the formation of carbon during the autothermal reforming (ATR) process since carbon can form deposits on the surface of the ATR catalyst and block the flow of reactants. Therefore, the presented work contains an analysis of the possibility of carbon formation at various values of the ATR process factors.

Autothermal and steam reforming processes were analyzed and compared in several previous studies which also included the experimental investigation of the ATR process $[1,2,3]$, and as a result most important ethanol ATR process factors were determined. The dependence of the ethanol ATR process on these process factors are studied in this work theoretically.

\section{Methodology and goal of the work}

The goal of the work is to determine the composition of the reforming products and the heat balance of ATR process depending on values of ethanol ATR process factors. The process factors considered in the analysis are the steam-to-carbon ratio $(\mathrm{S} / \mathrm{C})$, air-to-fuel ratio $(\lambda)$ and the temperature in the reactor $\left(\mathrm{T}_{\mathrm{ATR}}\right)$. The influence of the above process factors on carbon formation in the reaction products and the heat balance of the ATR process is also studied. As a result, the optimum values of process factors providing the maximum hydrogen yield and efficiency of the reforming process are determined. The efficiency of the reforming process is defined as the ratio of obtained hydrogen energy to the energy supplied to the system which includes energy contained in the supplied ethanol and external heat which is required for the reforming process.

In order to determine the optimum values of the ethanol ATR process, the range of values of $\mathrm{S} / \mathrm{C}, \lambda$ and $\mathrm{T}_{\mathrm{ATR}}$ chosen for chemical equilibrium calculations are as follows:

- $\mathrm{S} / \mathrm{C}=0,5-5$;

- $\lambda=0,1-0,7$

- $\mathrm{T}_{\mathrm{ATR}}=200-900^{\circ} \mathrm{C}$.

The choice of the range of values of the ethanol ATR process is based mainly on the results of previous experimental and theoretical studies of the ATR process $[4,5,6]$. The highest limiting value of $\mathrm{T}_{\text {ATR }}$ is defined by considering the temperature limit of ATR catalysts which shall not reach $1000^{\circ} \mathrm{C}$ since such high temperatures can damage the catalyst structure according to the information of producers. The lowest boundary value of $\mathrm{T}_{\mathrm{ATR}}$ is justified by the fact that the reforming reactions and formation of hydrogen start at approximately $200^{\circ} \mathrm{C}$. The chosen ranges of process factor values are also tested in the experiments made at Fraunhofer ISE [7]. The ethanol ATR process simulation model was made for the studies with ChemCAD software (http://www.chemstations.net/).

\section{Simulation model of the reforming system}

The simulation model of the ethanol ATR process is based on chemical equilibrium calculations, and the following chemical elements contained in the reactants and products were chosen for the calculations: $\mathrm{C}_{2} \mathrm{H}_{5} \mathrm{OH}$, $\mathrm{N}_{2}, \mathrm{O}_{2}, \mathrm{H}_{2} \mathrm{O}, \mathrm{H}_{2}, \mathrm{CO}, \mathrm{CO}_{2}, \mathrm{CH}_{4}, \mathrm{C}$. The equipment which forms the model of the ATR system is shown in Figure 1. Composition, flowrate, temperature and 
pressure for each incoming component (indicated in the text with number in braces - , \{\} ") is defined in the ChemCAD simulation. Pumps, heat exchangers, mixers, reactors, regulators, component separators and other system elements are identified in the text with numbers in brackets - ,()",

Ethanol $\{2\}$, water $\{4\}$ and air $\{1\}$ are supplied to the ethanol ATR process (Fig. 1) at a temperature of $20^{\circ} \mathrm{C}$ and pressure of 1 bar. Calculations are made for flowrate of supplied ethanol $1 \mathrm{~mol} / \mathrm{h}$. The amount of supplied water and air is varied depending on the chosen $\mathrm{S} / \mathrm{C}$ and $\lambda$ values by using the corresponding regulators $-\mathrm{S} / \mathrm{C}$ regulator (9) and $\lambda$ regulator (10). Reactants are supplied to the ATR system with the pumps (4), (5), (6). It is assumed in the calculations that the pressure loss in the system is zero and the efficiency of the pumps is 1. Streams of ethanol and water are mixed in the mixer (7) and vaporized in the heat exchanger (8). After mixing with air in the mixer (3), all reactants are heated up to the temperature of the ATR reactor in the heat exchanger (12). Afterwards, the reactants are supplied to the ATR reactor (2) where the reactions of the ATR process take place. The heat exchanger (11) cools down the reformed gas from the temperature of the ATR reactor to the average temperature required by the water gas shift reactor, which is $350^{\circ} \mathrm{C}$. In order to determine the dry gas composition of the products $\{11\}$, water $\{12\}$ is separated from the stream of the reaction products in the separator (1).

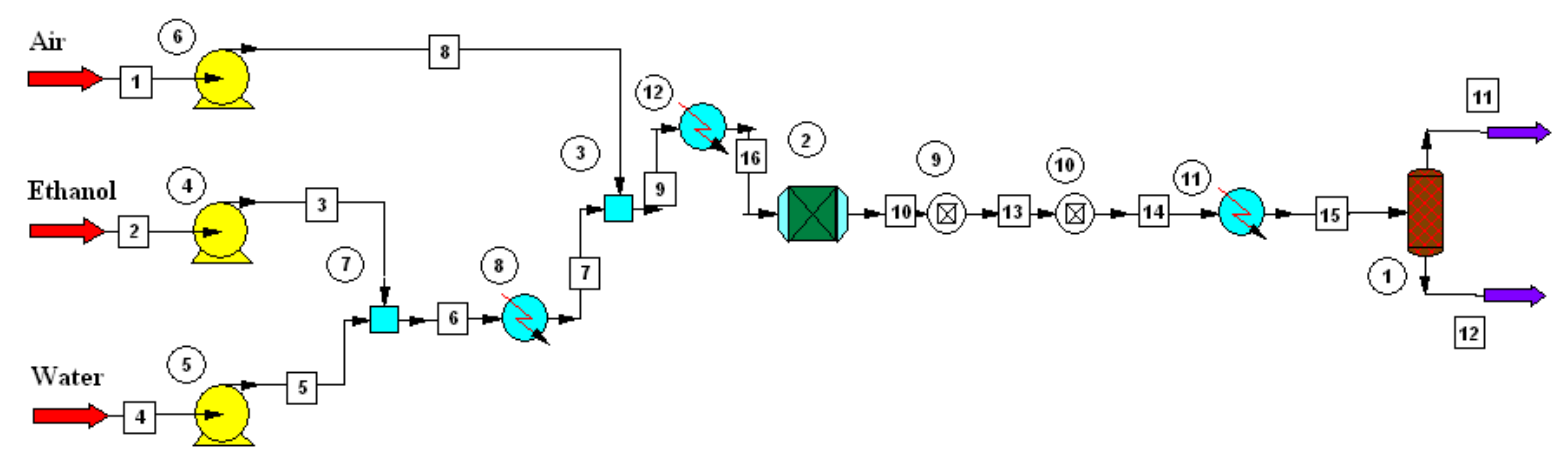

Fig.1. Schematics of ethanol ATR process simulation model

As was mentioned before, chemical equilibrium calculations are used in the simulation model, and these calculations traditionally are made by using the equilibrium constants of known chemical reactions. This approach can be used in calculations of relatively simple problems. However, if the equilibrium composition is determined under conditions when several reactions take place at the same time, as it is in the case of ethanol ATR process, calculations become very complicated. The most accurate method for solution of such complicate problems is the method of direct minimization of the Gibb's function of the system [4].

\section{Analysis of the influence of process factors on carbon formation}

Since carbon formation in the ATR reactor must be completely avoided, the analysis is started with calculations for the determination of the range of values of the ATR process factors which provide carbon free operation conditions. The results of calculations show that, within the studied range of $\lambda$ values, carbon is formed only if the value of $\mathrm{S} / \mathrm{C} \leq 1,5$ and $\mathrm{T}_{\mathrm{ATR}} \leq 800^{\circ} \mathrm{C}$, which can be explained by the fact that by increasing the amount of water steam in the system, it is possible to reduce the probability of carbon formation reactions [8]. Therefore, the range of values of the ATR process factors considered for further analysis may be narrowed down to the following boundaries: $\mathrm{S} / \mathrm{C}=0,5-1,5, \lambda=$ $0,1-0,7, \mathrm{~T}_{\mathrm{ATR}}=200-800^{\circ} \mathrm{C}$ (Fig. 2). 


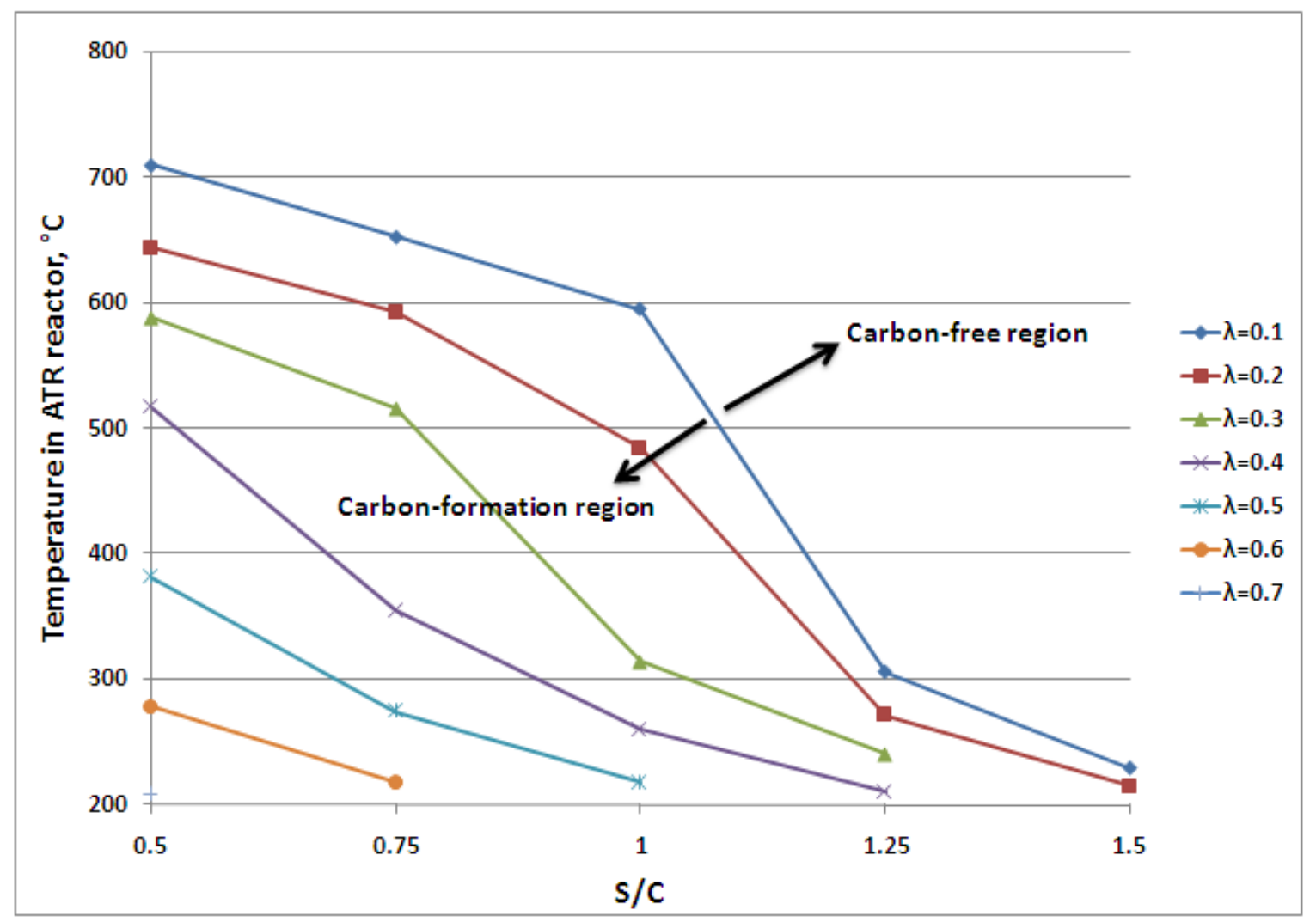

Fig. 2. Carbon formation and carbon-free regions depending on values of $\lambda, T_{A T R}$ and $S / C(p=1,3$ bar $)$

The curves in Figure 2 correspond to various values of $\lambda$ and separate the carbon formation regions from the regions where carbon is not formed. It can be seen that at lower $\mathrm{S} / \mathrm{C}$ values carbon formation can be avoided by an increase in the $\mathrm{T}_{\mathrm{ATR}}$ value or $\lambda$ value, which is in agreement with the results of theoretical studies of the ethanol ATR process made by other researchers $[4,9]$.

In the study of Rabenstein G. and Hacker V., it is concluded that in order to avoid carbon formation in the ATR reactor, it is necessary during experiments to use the following values of the ATR process factors: $\mathrm{S} / \mathrm{C}=$ $1-1,5, \lambda=0,17-0,33$ and $\mathrm{T}_{\mathrm{ATR}}>400^{\circ} \mathrm{C}$ [4]. However, the results of calculations show (Fig. 2) that at the temperature $\mathrm{T}_{\mathrm{ATR}}$ around $500^{\circ} \mathrm{C}$ and value of $\mathrm{S} / \mathrm{C}=1$ air-to-fuel ratio has to be above 0,2 to avoid carbon formation which is different from the previously mentioned lower value of $\lambda$. Within the range of $S / C$ values from 1 to 1,5 and $\mathrm{T}_{\mathrm{ATR}} \geq 600^{\circ} \mathrm{C}$ there should be no concern about the possibility of carbon formation at any value of $\lambda$ within the considered range $(0,1-0,7)$.

The results of the calculations show that a reduction in the $\lambda$ value facilitates carbon formation. To escape carbon formation in the ethanol ATR reactor at $\mathrm{S} / \mathrm{C} \leq 1$, the temperatures $\mathrm{T}_{\mathrm{ATR}} \geq 600^{\circ} \mathrm{C}$ and air-to-fuel ratio $\lambda \geq$ 0,3 values should be used. If $\mathrm{S} / \mathrm{C} \geq 1$ values of the temperatures $\mathrm{T}_{\mathrm{ATR}} \geq 300^{\circ} \mathrm{C}$ and $\lambda \geq 0,3$ will keep the reforming process in carbon-free region. Thus, it can be seen that, in order to avoid carbon formation at low values of $\mathrm{T}_{\mathrm{ATR}}$ and $\lambda$, it necessary to maintain high $\mathrm{S} / \mathrm{C}$ values which is supported by the theoretical studies of E.Önsan [10]. Increase of $\mathrm{S} / \mathrm{C}$ values also increases hydrogen concentration in the reaction products, but it increases the amount of heat required for heating and evaporation of water at the same time, therefore it is important to analyze the impact of $\mathrm{S} / \mathrm{C}$ values on the composition of the reaction products and the heat balance of the reforming process.

\section{Optimization of hydrogen yield}

Optimization of hydrogen yield and process efficiency with the objective functions depending on the considered process factors $\mathrm{S} / \mathrm{C}, \mathrm{T}_{\mathrm{ATR}}$ and $\lambda$ is presented in this chapter.

The optimum points of $\mathrm{H}_{2}$ yield within the range of values of $\mathrm{S} / \mathrm{C}$ from 0,5 to 5 and $\lambda$ values from 0,1 to 0,7 are found by using the following objective function:

$$
\frac{\dot{n} H_{2}\left(T_{A T R}, S / C, \lambda\right)}{\dot{n} C_{2} H_{5} O H} \rightarrow \max
$$

where $\dot{n}$ is the number of moles.

The objective function (1) is maximized at the given $\mathrm{S} / \mathrm{C}$ and $\lambda$ values by varying the value of the temperature $\mathrm{T}_{\mathrm{ATR}}$ in the ATR reactor. 


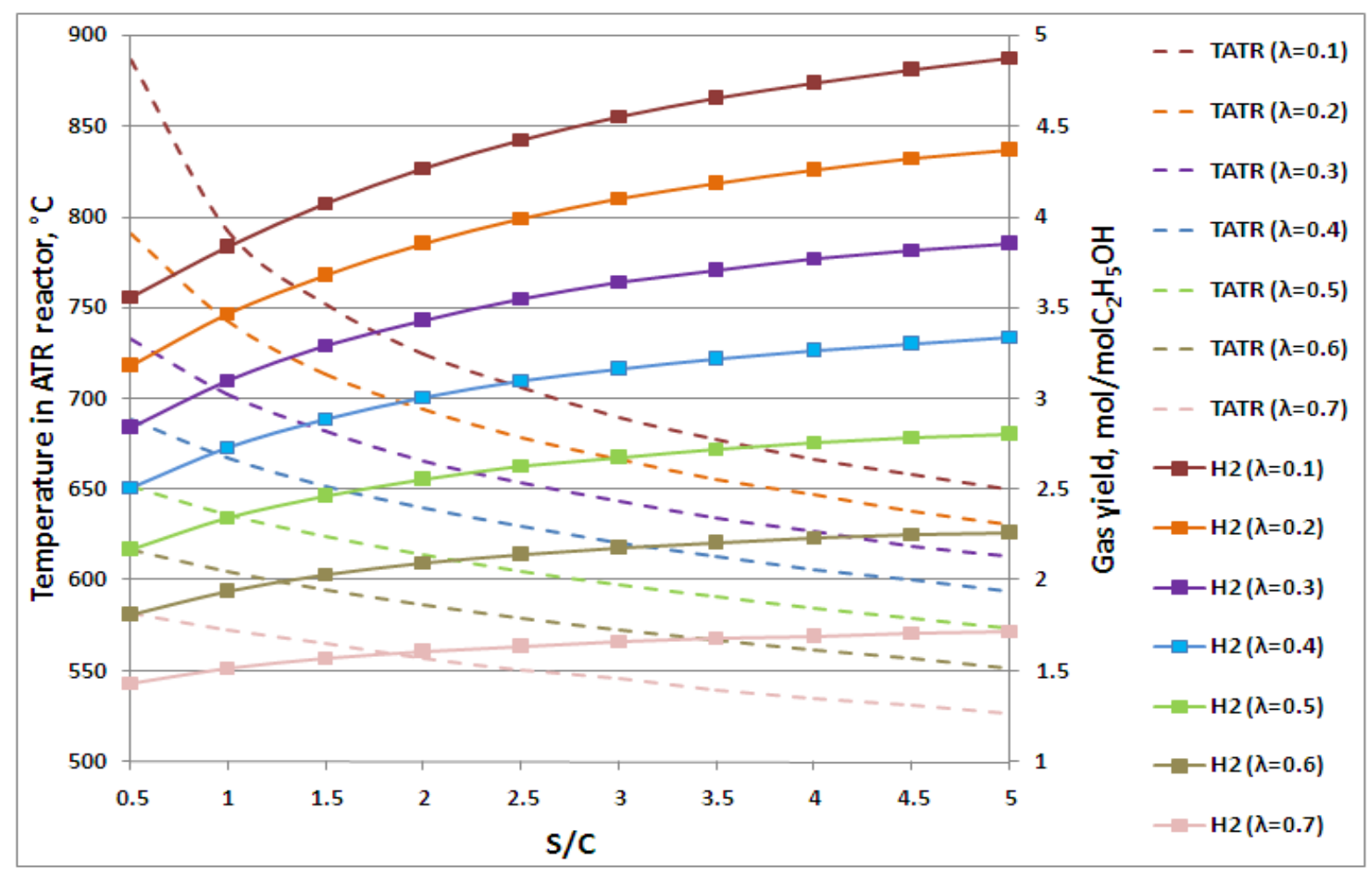

Fig.3. The optimum values of $\mathrm{H}_{2}$ yield and corresponding $\mathrm{T}_{\mathrm{ATR}}, \lambda$ and $\mathrm{S} / \mathrm{C}$ values $(\mathrm{p}=1,3$ bar)

The values of the objective function (secondary y axis) and the corresponding $\mathrm{T}_{\mathrm{ATR}}$ values (primary y axis) at chosen values of $\mathrm{S} / \mathrm{C}$ and $\lambda$ for the whole range of the studies are shown in Figure 3. It can be observed that the $\mathrm{H}_{2}$ yield increases and the corresponding temperature in the reactor $\mathrm{T}_{\mathrm{ATR}}$ decreases if the $\mathrm{S} / \mathrm{C}$ value is increased and the $\lambda$ value is decreased. The maximum value of hydrogen yield, which is 4,87 $\mathrm{mol} / \mathrm{mol} \mathrm{C}_{2} \mathrm{H}_{5} \mathrm{OH}$ within the studied range of process factor values is reached at $\mathrm{S} / \mathrm{C}=5, \lambda=0,1$ and $\mathrm{T}_{\mathrm{ATR}}=$ $650^{\circ} \mathrm{C}$

\section{Optimization of process efficiency}

Increase of the $\mathrm{S} / \mathrm{C}$ value promotes hydrogen yield but requires more heat to be supplied for heating of the reactants, and since the heat balance is an important part in design of a reformer system, it is also important to consider the amount of heat supplied to the system in optimization .

One of the most important parameters which characterize operation of the reforming process is the efficiency defined as a ratio of obtained energy of hydrogen and total heat energy supplied to the process.
Therefore, the following objective function of process efficiency $(\eta)$ is used for the optimization:

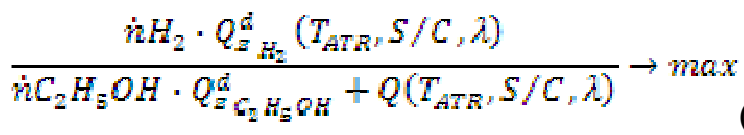

where

$\mathrm{Q}$ - required heat supply to the system, $\mathrm{kJ} / \mathrm{mol}$;

$Q_{G_{Z} H_{z} O H}^{d}-$ lower heating value of ethanol, $\mathrm{kJ} / \mathrm{mol}$;

$Q_{E_{H z}}^{d}$ - lower heating value of hydrogen, $\mathrm{kJ} / \mathrm{mol}$.

Figure 4 presents the optimum values of process efficiency (secondary y axis) and the corresponding values of $\mathrm{T}_{\mathrm{ATR}}$ (primary y axis) depending on $\mathrm{S} / \mathrm{C}$ and $\lambda$ values for the studied range of values. It can be noticed that the optimum values of efficiency at a certain value of $\mathrm{S} / \mathrm{C}$ increases (Fig. 4), if $\lambda$ value is decreased. The optimum value of $\mathrm{S} / \mathrm{C}$ giving the maximum value of efficiency exists at a certain value of $\lambda$ (Fig. 4) and the optimum value of $\mathrm{S} / \mathrm{C}$ increases when $\lambda$ value is decreased. It can also be observed that as the $\mathrm{S} / \mathrm{C}$ value decreases, the dependence of process efficiency on the $\lambda$ value decreases (Fig. 4). The optimum values of $\mathrm{T}_{\mathrm{ATR}}$ decreases with increasing values of $\mathrm{S} / \mathrm{C}$ and $\lambda$. 


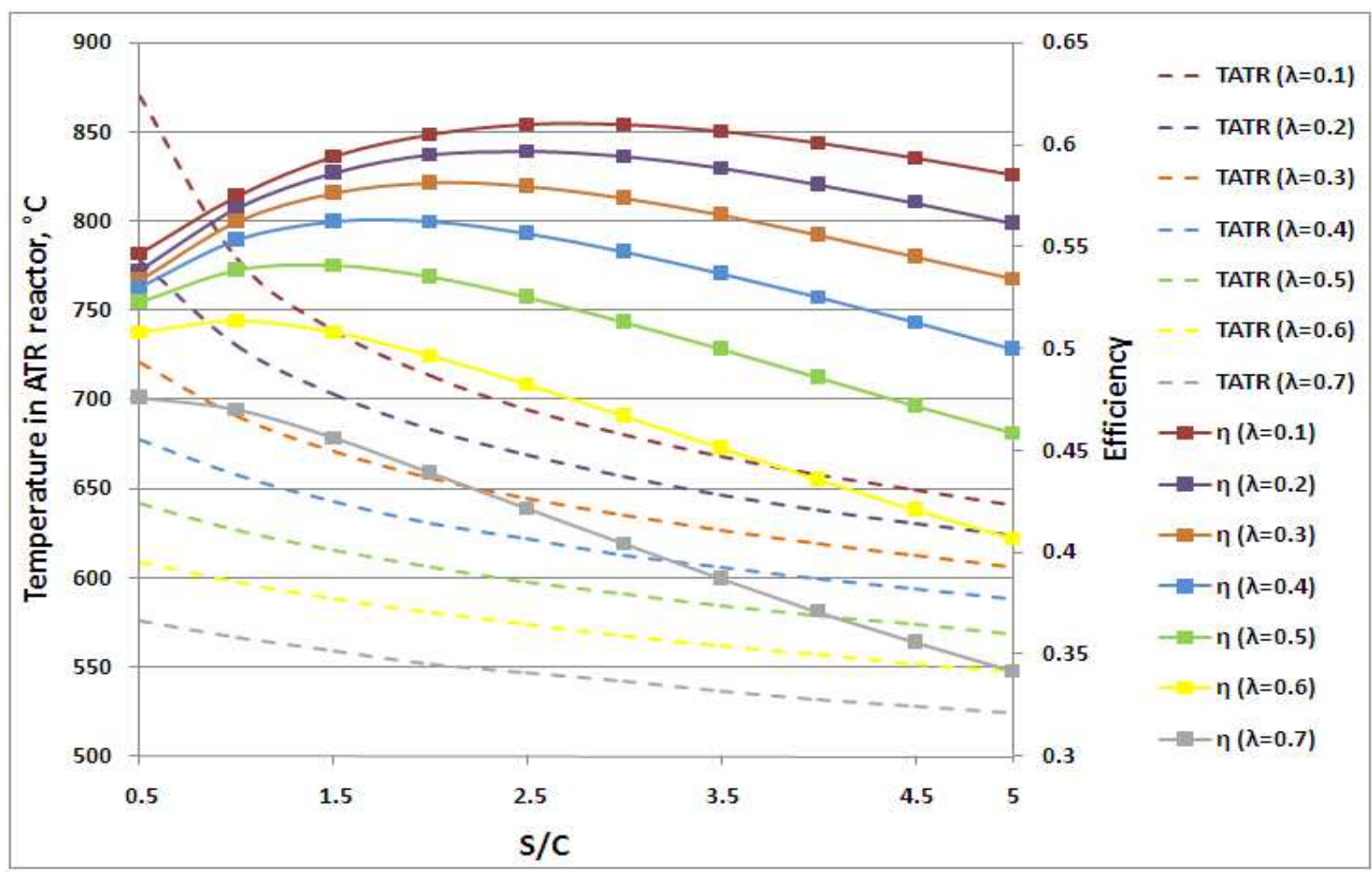

Fig. 4. The optimum values of process efficiency and the corresponding $T_{A T R}$ values depending on $\lambda$ and $S / C(p=$ 1,3 bar)

The highest value of efficiency $\eta=0,61$ within the studied range of process factor values can be obtained at $\lambda=0,1 ; \mathrm{S} / \mathrm{C}=2,5-3 ; \mathrm{T}_{\mathrm{ATR}}=680-695^{\circ} \mathrm{C}$. Hydrogen yield of $4,41-4,55 \mathrm{~mol} / \mathrm{molC}_{2} \mathrm{H}_{5} \mathrm{OH}$ with $\mathrm{CO}$ yield of $0,74-0,86 \mathrm{~mol} / \mathrm{molC}_{2} \mathrm{H}_{5} \mathrm{OH}$ and $\mathrm{CH}_{4}$ yield of $0,02-0,04 \mathrm{~mol} / \mathrm{molC}_{2} \mathrm{H}_{5} \mathrm{OH}$ is achieved at these conditions, and the required heat supply to the system (Q) is within the range of $435-493 \mathrm{~kJ} / \mathrm{molC}_{2} \mathrm{H}_{5} \mathrm{OH}$. In the stoichiometric analysis of the ethanol ATR process conducted by B.F. Hagh [6], it was found that the maximum efficiency can be achieved at the $\mathrm{T}_{\text {ATRie }}$ approximately $670^{\circ} \mathrm{C}, \lambda=0,325$ and $\mathrm{S} / \mathrm{C}=3$ which, except for the $\lambda$ value, is rather close to the optimum values of process factors found in this work. For the value of $\lambda=0,3$, the optimum value of efficiency reduces to 0,58 and that is achieved at the value of $\mathrm{S} / \mathrm{C}$ $=2$ and $\mathrm{T}_{\mathrm{ATR}}=656^{\circ} \mathrm{C}$ (Fig. 4). If the $\lambda$ value is increased even further to the range of $0,4-0,5$ then the optimum of efficiency is $0,56-0,54$, and this value is reached at $\mathrm{S} / \mathrm{C}$ value around 1.5 and $\mathrm{T}_{\mathrm{ATR}}=643-$ $616^{\circ} \mathrm{C}$ (Fig. 4).

\section{Conclusions}

Results of theoretical studies of the ethanol ATR process by using chemical equilibrium calculations shows that carbon formation can be expected only if the value of $\mathrm{S} / \mathrm{C}$ is reduced below 1,5 . Lower $\mathrm{S} / \mathrm{C}$ values can be used and carbon formation in the ethanol ATR reactor can still be avoided if the values of $\mathrm{T}_{\mathrm{ATR}}$ or $\lambda$ are increased above a certain threshold.

The highest value of $\mathrm{H}_{2}$ yield within the studied range of process factors is equal to $4.87 \mathrm{~mol} / \mathrm{mol} \mathrm{C}_{2} \mathrm{H}_{5} \mathrm{OH}$, and this value is achieved at $\lambda=0,1 ; \mathrm{S} / \mathrm{C}=5$ and $\mathrm{T}_{\mathrm{ATR}}=$ $650^{\circ} \mathrm{C}$. Since for the design of the ATR reactor it is also necessary to consider heat supply to the process, analysis of process efficiency was made and the optimum of the ethanol ATR process efficiency is also found in the work. It was detected that the maximum efficiency of 0,61 can be achieved at the following values of process factors: $\mathrm{S} / \mathrm{C}=2,5-3 ; \mathrm{T}_{\mathrm{ATR}}=685-$ $690^{\circ} \mathrm{C} ; \lambda=0,1$. Higher values of $\mathrm{S} / \mathrm{C}$ will require larger heat supply to the process. Therefore, if the carbon formation has to be avoided and the reforming process has to be operated at the maximum process efficiency then the values of $\mathrm{S} / \mathrm{C}$ are confined within the region from 1,5 to 3 . If values of $\lambda$ above 0,1 are used in the process then the highest boundary of $\mathrm{S} / \mathrm{C}$ reduces to approximately 2,5 .

\section{References}

1. Optimization of bio-ethanol autothermal reforming and carbon monoxide removal processes / Markova D., Bažbauers G., Valters K., Rochlitz L., Alhucema Arias R., Weuffen C. // Journal of Power Sources. - 193. Issue 1 (2009). P.9-16.

2. Markova D., Valters K., Bažbauers G. Reforming of bioethanol to hydrogen for use in fuel cell 
cogeneration plants // The Scientific Proceedings of Riga Technical University. 13th series, Environment and climate technologies. - 1th volume (2008), P.61-67.

3. Markova D., Bažbauers G. Comparison of ethanol steam and autothermal reforming processes // The Scientific Proceedings of Riga Technical University. 4th series, Energy and Electrotehnic, Energy systems and environment. - 21th volume (2007), P.23-28.

4. Rabenstein G., Hacker V., Hydrogen for fuel cells from ethanol by steam-reforming, partial-oxidation and combined auto-thermal reforming: A thermodynamic analysis // Journal of Power Sources. - 185 (2008). P.1293-1304.

5. Equilibrium products from autothermal processes for generating hydrogen-rich fuel-cell feeds / Semelsberger T.A., Brown L.F., Borup R.L., Inbody M.A. // International Journal of Hydrogen Energy. - 29 (2004). P.1047-1064.

6. Hagh B.F., Stoichiometric analysis of autothermal fuel processing // Journal of Power Sources. - 130 (2004). P.85-94.

7. Markova D., Bažbauers G., Weuffen C. Bioethanol powered microreformer for PEM-fuel cell with up to $300 \mathrm{~W}$ output capacity // Scientific proceedings of Riga Technical University, Energy and Electrical Engineering $-17^{\text {th }}$ volume (2006), P.144-149.

8. Larminie J., Dicks A. Fuel Cell Systems Explained. - Chichester: John Willey \& Sons, Ltd., 2000. - P.194.

9. Ahmed S., Krumpelt M., Hydrogen from hydrocarbon fuels for fuel cells // International Journal of Hydrogen Energy. - 26 (2001). P.291301.

10. Önsan Z.I., Catalytic Processes for Clean Hydrogen Production from Hydrocarbons // Turk. J. Chem. - 31 (2007), P.531-550.
Darja Markova, Kārlis Valters, Gatis Bažbauers, Etanola autotermiskā pārveidošanas procesa optimizācija ar ķīmiskā līdzsvara aprēḳiniem

Darbā, izmantojot izveidoto etanola autotermiskā pārveidošanas procesa imitācijas modeli ChemCAD vidē, ar ķīmiskā lìdzsvara aprēķinu palīdzību tiek aplūkots kā svarīgākie pārveidošanas procesa faktori ietekmē oglekļa veidošanās iespējamību, ūdeņraža ieguves vērtību un procesa lietderības koeficientu. Analizētie procesa faktori ir ūdens tvaika-oglekla attiecība $S / C$, gaisa patēringa koeficients $\lambda$ un temperatūra pārveidošanas reaktorā $T_{A T R}$. Tā kā pārveidošanas procesu mērķis ir sasniegt iespējami augstāku $\mathrm{H}_{2}$ koncentrāciju pārveidotajā gāzē, vienlaicīgi nodrošinot maksimāli lielu procesa lietderības koeficientu, tika veikta optimizācija ar mērķa funkcijām, kas iekļāva ūdeņraža ieguvi un procesam pievadìtā siltuma daudzumu. Rezultātā tika noskaidrots, ka maksimālais lietderības koeficients, kas ir definèts kā iegūtā ūdeņraža energijas un procesam pievadītās energíijas attiecība, aplūkotajā faktoru vērtību diapazonā ir 0,61, kas tiek sasniegts pie $\lambda$ vērtības $0,1, S / C$ vērtības $2,5-3$ un temperatūras reaktorā $T_{A T R} 680-695^{\circ} \mathrm{C}$. Šajos apstāklos üdeņraža ieguve ir 4,41-4,55 $\mathrm{mol} / \mathrm{mol} \mathrm{C}_{2} \mathrm{H}_{5} \mathrm{OH}$.

Darja Markova, Kārlis Valters, Gatis Bažbauers, Optimization of ethanol autothermal reforming process with chemical equilibrium calculations

The dependence of carbon formation, hydrogen yield and efficiency of the ethanol autothermal reforming process on critical process factors is studied in the work by using chemical equilibrium calculations with a process simulation model made in the ChemCAD environment. The studied process factors are carbon-to-steam ratio $S / C$, air-to-fuel ratio $\lambda$ and temperature in the reactor $T_{A T R}$. Since the goal of the reforming process is to achieve possibly higher values of $\mathrm{H}_{2}$ concentration in the reforming gas, by operating reformer at the maximum efficiency at the same time, the optimization of the reforming process was done by using objective functions which include hydrogen yield and the amount of heat supplied to the process. As a result it was found that the maximum process efficiency, which is defined as the ratio of obtained hydrogen energy to the energy supplied to the process in the studied range of process factors is 0,61 , and this value can be achieved at $\lambda$ value of $0,1, S / C$ values of 2,5-3 and temperatures in the reactor $T_{A T R} 680-695^{\circ} \mathrm{C}$. Hydrogen yield under these conditions is 4,41-4,55 $\mathrm{mol} / \mathrm{molC}_{2} \mathrm{H}_{5} \mathrm{OH}$.

\footnotetext{
Дарья Маркова, Карлис Валтерс, Гатис Бажбауэрс, Оптимизация процесса автотермического реформинга этанола с расчётами химического равновесия

$B$ работе, используя созданную в среде ChemCAD имитационную модель процесса автотермического реформинга этанола, с помощью расчётов химического равновесия рассмотрено как наиболее важные факторы
} 
прочесса реформинга влияют на возможность образования углерода, величину добычи водорода и на коэффициент полезного действия прочесса. Анализируемые факторы прочесса - отночение пара воды к углероду $S / C$, коэффициент использования воздуха $\lambda$ и температура в реакторе реформинга $T_{A T R}$. Так как иелью прочессов реформинга является достижение наибольшей концентрации $\mathrm{H}_{2}$ в преобразованном газе, одновременно обеспечивая максимальный коэффициент полезного действия прочесса, была произведена оптимизация с иелевыми функциями, которые включают в себя добычу водорода и прочессу подведённое количество тепла. В результате было определено, что максимальный коэффициент полезного действия, который определён как отношение количества энергии полученного водорода к количеству энергии подведённой прочессу, в рассмотренном диапазоне значений факторов, равен 0,61, что может быть достигнуто при значении $\lambda$ 0,1, значении $S / C$ 2,5 - 3 и при значении температуры в реакторе $T_{A T R} 680-695^{\circ} \mathrm{C}$. При таких условиях получение водорода равно 4,41-4,55 моль/моль $\mathrm{C}_{2} \mathrm{H}_{5} \mathrm{OH}$. 